\title{
Potential influence of automated volumetry on treatment response classifications in lung cancer lesions
}

\author{
Kaveh Akbari", Alexandra Barthol, Irene Schnauder, v Wunn, Elmar Brehm, Bernd Lamprecht, Franz Fellner \\ From International Cancer Imaging Society (ICIS) 14th Annual Teaching Course \\ Heidelberg, Germany. 9-11 October 2014
}

\section{Purpose}

To evaluate the potential influence of automated volumetry on treatment response classifications in lung cancer in comparison to manual unidimensional measurements.

\section{Material and methods}

60 patients (41 men, 19 women, mean age $61.8 \pm 9.4$ years) with histopathologically verified lung cancer were included in this retrospective study.

For each patient, up to 2 target lesions were quantitatively evaluated in a baseline and two follow-up CT scans (77 lesions, 154 response classifications) by two independent radiologists. Hilar and mediastinal masses, as well as lesions surrounded by atelectasis were excluded.

For each lesion a unidimensional diameter measurement, as well as an automated CT-volumetry was performed. In the follow-up studies, the response evaluation was assessed using RECIST compared to volume equivalents of RECIST with converted thresholds $(-65 /+73 \%)$.

\section{Results}

The results of the manual one-dimensional measurements varied between the two observers by $6.34 \pm 17.12 \%$, affecting the volume to the power of 3 , whereas the volumetric measurements varied only by $3.33 \pm 6.66 \%$.

In $16.9 \%(26 / 154)$ of the cases the volumetric assessment led to a different response classification.

In $13 \%(20 / 154)$ of the cases the different response classification would have an effect on therapeutic decisions.

* Correspondence: kaveh.akbari@akh.linz.at

Department of Radiology, General Hospital Linz, Linz, Austria

\section{Conclusion}

The volumetric assessment of lung cancer lesions can reflect the tumour burden more appropriately and therefore has a significant effect on response classifications and therapeutic decisions.

Published: 9 October 2014

doi:10.1186/1470-7330-14-S1-P30

Cite this article as: Akbari et al:: Potential influence of automated volumetry on treatment response classifications in lung cancer lesions. Cancer Imaging 2014 14(Suppl 1):P30.
Submit your next manuscript to BioMed Central and take full advantage of:

- Convenient online submission

- Thorough peer review

- No space constraints or color figure charges

- Immediate publication on acceptance

- Inclusion in PubMed, CAS, Scopus and Google Scholar

- Research which is freely available for redistribution

Submit your manuscript at www.biomedcentral.com/submit
( Biomed Central 